\title{
Examination of Adipocere Formation in a Cold Water Environment
}

Shari. L. Forbes ${ }^{a, *}$, Matthew. E.A. Wilson ${ }^{\text {a }}$, Barbara. H. Stuart ${ }^{b}$

${ }^{a}$ Faculty of Science, University of Ontario Institute of Technology, 2000 Simcoe St N, Oshawa, ON, L1H 7K4, Canada

${ }^{\mathrm{b}}$ Centre for Forensic Science, University of Technology, Sydney, PO Box 123, Broadway, NSW, 2007, Australia

* Corresponding author. Phone: +1 905721 3050, Fax: +1 9057213304

Email: shari.forbes@uoit.ca 


\begin{abstract}
Adipocere is a late stage postmortem decomposition product that forms from the lipids present in soft tissue. Its formation in aquatic environments is typically related to the presence of a moist, warm, anaerobic environment, and the effect of decomposer microorganisms. The ideal temperature range for adipocere formation is considered to be $21-45^{\circ} \mathrm{C}$ and is correlated to the optimal conditions for bacterial growth and enzymatic release. However, adipocere formation has been reported in cooler aquatic environments at considerable depths. This study aimed to investigate the chemical process of adipocere formation in a cold freshwater environment in Lake Ontario, Canada. Porcine tissue was used as a human tissue analogue and submerged at two depths (i.e. 10 and 30 feet) in the trophogenic zone of the lake. Samples were collected at monthly postmortem submersion intervals and analysed using Diffuse Reflectance Infrared Fourier Transform (DRIFT) spectroscopy to provide a qualitative profile of the lipid degradation and adipocere formation process. Early stage adipocere formation occurred rapidly in the cold water environment and proceeded to intermediate stage adipocere formation by the second month of submersion. However, further adipocere formation was inhibited in the third month of the study when temperatures approached the freezing point. The depth of submergence did not influence the chemical conversion process as similar stages of adipocere formation occurred at both depths investigated. The study demonstrated that adipocere can form rapidly, even on small amounts of soft tissue, which may be representative of dismembered or disarticulated limbs discovered in an aquatic environment.
\end{abstract}

Keywords: adipocere, decomposition, DRIFT spectroscopy, Lake Ontario, forensic taphonomy 


\section{Introduction}

Adipocere is a late stage postmortem decomposition product that forms from the adipose tissue present in a body [1-5]. The process of adipocere formation is initiated by intrinsic lipases that lead to the degradation of the major constituents of lipids i.e. triglycerides [6]. During this process the neutral fats are converted into fatty acids which cause a disturbance in the equilibrium that exists within the fat cell (adipocyte). During decomposition, the lipid membrane of the adipocyte, which is comprised of glycerol, fatty acids, phospholipids, and proteins, absorbs water into the cell and will eventually rupture releasing the fatty acids and other components. The fatty acids are subsequently hydrolyzed and hydrogenated by chemical decomposition [3, 7] to yield saturated fatty acids including myristic, palmitic, and stearic acid; unsaturated fatty acids including palmitoleic acid, oleic and linoleic acid; as well as calcium salts of fatty acids and hydroxy and oxo- fatty acids [2,5,8-10].

The factors that influence adipocere formation in an aquatic environment are generally accepted to be the presence of fatty tissue, a moist, warm, anaerobic environment, and the presence of decomposer microorganisms [7]. Adipocere typically develops in an anaerobic environment and is facilitated by degradative anaerobes such as Clostridium perfringens and Clostridium frigidicanes [11]. The action of these microorganisms creates an alkaline environment that inhibits bacterial growth, thus arresting decomposition. Moisture is necessary for the commencement of bacterial and enzymatic activities involved in adipocere formation, however it is not an essential prerequisite for the continuation of the process $[3,8,10]$. The presence of fat and water will compensate each other to such a degree that at least small amounts of adipocere will likely form and when both are present in large quantities its formation is almost guaranteed [12]. Although adipocere typically demonstrates a hard, white exterior with a crumbly texture, it can also be present as a soft, greasy substance depending on the environment in which it is found and the stage of formation. Early stage adipocere formation will often demonstrate this soft consistency and will contain high levels of unsaturated fatty acids when analysed $[4,13]$. As the body loses moisture due to the hydrolysis process, the tissue will become dehydrated and produce conditions unfavourable to bacterial proliferation [14]. At this point, the adipocere product will be relatively stable and brittle due to the higher melting points of the saturated and hydroxy-fatty acids that have formed. 
It is well established that temperature is an important factor in the process of decomposition and similarly it has been identified as an influencing factor of adipocere formation in aquatic environments [7]. The ideal temperature range is considered to be $21-45^{\circ} \mathrm{C}$ and is correlated to the optimal conditions for bacterial growth and enzymatic release [7, 15-17]. Adipocere formation has been reported in cooler temperatures, however the rate of development is considerably slowed. Reports suggest that adipocere formation in cold water $\left(4^{\circ} \mathrm{C}\right)$ will take approximately 12-18 months [17] while formation in cool water $\left(15-22^{\circ} \mathrm{C}\right)$ will take at least 2-3 months [16]. Typically rapid adipocere formation (e.g. days or weeks) is only associated with extremely warm water conditions [1].

Several studies $[1,18]$ have contradicted these findings by reporting the formation of adipocere on cadavers recovered in cool water environments at considerable depth. Kahana et al. [1] report adipocere formation on cadavers 38 days after the time of immersion in seawater. The bodies were recovered from depths of approximately $65-85 \mathrm{~m}$ at temperatures of $10-12^{\circ} \mathrm{C}$. However, the surface water temperature was considerably higher $\left(20-24^{\circ} \mathrm{C}\right)$ at the time of immersion and this may have contributed to rapid decomposition and/or adipocere formation in the early postmortem period. Dumser et al. [18] also report adipocere formation on a body recovered from a depth of 580m after approximately 3 months immersion in cool seawater $\left(\sim 13^{\circ} \mathrm{C}\right)$. Due to the depth of both studies, adipocere formation is believed to have occurred in the tropholytic zone [18].

The aim of this study is to investigate adipocere formation in a cool/cold freshwater environment in the trophogenic zone near the surface. Although studies have reported observational adipocere formation in cool seawaters, the degree of adipocere formation has not been chemically confirmed at these temperatures in freshwater environments. Furthermore, it is of interest in forensic science to investigate shallow depths that are more realistic of a forensic scenario and to confirm whether depth is an influencing factor on the formation of adipocere in aquatic environments. The chemical composition of adipocere has been determined using diffuse reflectance infrared Fourier transform (DRIFT) spectroscopy. Previous studies have highlighted the advantages of using infrared spectroscopy $[5,19-20]$ to elucidate structural isomers and to avoid lengthy sample preparation often associated with chromatographic methods [4, 21]. 


\section{Materials and method}

\section{Experimental design}

The decomposition site chosen for this study was Lake Ontario located in southern Ontario, Canada. Lake Ontario is a freshwater body that is the smallest of the Great Lakes, spanning a surface area of $18,960 \mathrm{~km}^{2}$. The maximum depth is $244 \mathrm{~m}$ deep and the average depth is $86 \mathrm{~m}$. Surface water temperatures range from $0-4^{\circ} \mathrm{C}$ in the winter and between $12-20^{\circ} \mathrm{C}$ in the summer months. Approximately 85 fish species have been recorded in Lake Ontario and the most abundant native species include yellow and brown bullhead, American eel, northern pike, yellow perch, walleye, sauger, and smallmouth and largemouth bass. Various species of amphibians and reptiles inhabit Lake Ontario along with numerous invertebrates such as molluscs, zebra mussels and crayfish [22].

Samples of adipose tissue were obtained from domestic pigs that were reared on similar diets for commercial use. Due to ethical restrictions preventing the use of human tissue, porcine tissue was used to model human decomposition. Eighteen (18) pork hind legs were purchased for the purpose of the experiment and contained all layers of soft tissue and bone. Nine (9) samples each were attached to two anchoring systems using wire threaded through the tibia. The systems were submerged and anchored at approximately 10 feet $(3 \mathrm{~m})$ and 30 feet $(9 \mathrm{~m})$, respectively. These depths were chosen to ensure they were within the trophogenic zone and to represent depths commonly associated with body recoveries from Lake Ontario (Pers. Comm. Sgt. D. Little, Toronto Police Service Marine Unit).

\section{Sample collection}

The experiment was conducted over a three month period from September - December, 2008. Control samples containing all layers of soft tissue were collected from each of the 18 pork hind legs prior to submergence in Lake Ontario and were stored in a freezer $\left(-20^{\circ} \mathrm{C}\right)$ until analysis. The control samples allowed for a comparison of the lipid composition between fresh adipose tissue and adipocere. Water temperature was measured weekly at both depths and visual and photographic observations were recorded for the 3 month study period to determine biomass loss. Samples of soft tissue (3 replicates) were collected at one, two and three month postmortem submersion intervals. All samples were stored in a freezer $\left(-20^{\circ} \mathrm{C}\right)$ until analysis. 


\section{DRIFT spectroscopy analysis}

Tissue samples were thawed and lyophilized using a Labconco Freeze Dryer for approximately 48 hours. Samples were ground with powdered potassium bromide $(\mathrm{KBr})$ using a mortar and pestle in a ratio of approximately 1:10 and placed in an aluminium oxide microsampling cup. Background spectra were collected using powdered $\mathrm{KBr}$. The infrared spectrum of each sample was recorded using a Smart Collector diffuse reflectance infrared sampling accessory attached to a Thermo Electron Nicolet 4700 Fourier transform infrared spectrometer. Spectra were scanned over the range $4000-500 \mathrm{~cm}^{-1}$ for each sample and 128 scans were recorded with a resolution of $4 \mathrm{~cm}^{-1}$. Samples were analysed in triplicate.

\section{Results and discussion}

\section{Decomposition process}

After one month submersion, the samples were emitting a distinctive decomposition odour at both depths and appeared to be in the bloat stage of decomposition as evidenced by the floating samples. Green algae was observed on the outer skin layer, however, the soft tissue still demonstrated a fresh pink colour when excised. A grey-white waxy substance, characteristic of fat decomposition, was observed in small amounts on all samples. Minimal biomass loss had occurred and there was no evidence of extensive scavenging.

Samples collected after two months submersion demonstrated extensive algal growth and sloughing of the dermal layers. The underlying tissue appeared soft and pliable. The waxy substance was observed to cover a larger surface area of the exposed tissue and the samples continued to generate a decomposition odour. Biomass loss as a result of decomposition and scavenging was minimal.

Samples collected after three months submersion demonstrated characteristic adipocere formation. The samples submerged at ten feet contained a soft, greasy white substance while those submerged at thirty feet contained a hard, crumbly white substance. There was no evidence of extensive scavenging and the biomass appeared greater as a result of the adipocere formation preserving the soft tissue. 


\section{Temperature data}

Water temperature was recorded at both depths and is reported in Figure 1. The experiment spanned the end of summer, fall and early winter seasons. There was a decreasing trend throughout the duration of the study and temperatures were typical for that time of year in southern Ontario [23]. The water temperatures at the 10 and 30 feet depths were not statistically different ( $>0.05)$. At the completion of the experiment, snow had started to accumulate and the temperatures approached zero $\left({ }^{0} \mathrm{C}\right)$. Sections of Lake Ontario had frozen close to the shore however the experimental sites did not freeze.

\section{DRIFT spectroscopy}

The characteristic infrared bands associated with adipose tissue and adipocere have been previously reported and result from the presence of triglycerides $\left(\sim 1740 \mathrm{~cm}^{-1}\right)$, fatty acids $\left(\sim 1710-1700 \mathrm{~cm}^{-1}\right)$, and salts of fatty acids $\left(\sim 1580-1540 \mathrm{~cm}^{-1}\right)[5,19-20]$. The ratio of these bands is typically used to monitor the lipid decomposition process from adipose tissue to adipocere and to estimate the stage of adipocere formation. Early stage adipocere formation is associated with high amounts of triglycerides, whereas the intermediate and advanced stages of adipocere formation typically show little evidence of triglycerides and large amounts of unsaturated and saturated fatty acids, coupled with salts of fatty acids and hydroxy fatty acids. Representative spectra are shown and were chosen based on their clarity and representation of the characteristic bands which were identified in each of the replicate samples.

Figure 2 is a representative spectrum of the adipose tissue samples collected the beginning of the study. A strong band appears at $1743 \mathrm{~cm}^{-1}$, which is characteristic of triglyceride $\mathrm{C}=\mathrm{O}$ stretching. The strong bands in the region $2950-2800 \mathrm{~cm}^{-1}$ are due to C-H stretching and provide a means for estimating the relative intensity of the $\mathrm{C}=\mathrm{O}$ bands. Importantly, the spectrum does not show any evidence of free fatty acids or salts of fatty acids.

The spectra in Figure 3 are representative of the samples collected after a one month postmortem submersion interval at 10 and 30 feet, respectively. Both samples show similar bands and are distinctly different from the adipose tissue spectrum. Strong $\mathrm{C}=\mathrm{O}$ stretching bands around $1708 \mathrm{~cm}^{-1}$ are evidence of the presence of free fatty acids and the small shoulder around $1740 \mathrm{~cm}^{-1}$ indicates a reduction in the amount of triglycerides present in the samples. The presence of salts of fatty acids can be evidenced by the appearance of carboxylate C-O stretching bands in the region $1580-1540 \mathrm{~cm}^{-1}$. The $\mathrm{O}-\mathrm{H}$ stretching modes are demonstrated in the regions 
$3400-3200 \mathrm{~cm}^{-1}$ and $2700-2600 \mathrm{~cm}^{-1}$, the latter of which can be attributed to hydroxy-fatty acids. The decrease in triglycerides coupled with the increase in free fatty acids is evidence that the lipid decomposition process has commenced and adipocere has started to form on the samples after one month submergence. The chemical composition of the one month samples suggests that the adipocere is in an early to intermediate stage of formation and is clearly interacting with the surrounding aquatic environment to form salts of fatty acids.

Representative spectra for the samples collected after two months submersion at 10 and 30 feet depths are shown in Figure 4. The samples show minimal changes when compared to the one month samples and are predominantly characterized by strong fatty acids bands ( 1700-1710 $\mathrm{cm}^{-1}$ ) and weak salts of fatty acids bands (1580-1540 $\left.\mathrm{cm}^{-1}\right)$. A shoulder at $\sim 1740 \mathrm{~cm}^{-1}$ demonstrates small amounts of triglycerides still remaining. Bands in the $1500-1400 \mathrm{~cm}^{-1}$ region are associated with methylene-bending modes and result from the conversion of unsaturated to saturated fatty acids. The $\mathrm{O}-\mathrm{H}$ stretching modes are still present above $3000 \mathrm{~cm}^{-1}$ and in the region $2700-2600 \mathrm{~cm}^{-1}$. Chemically the composition has not significantly changed however the intensity of the bands has increased (as shown on the absorbance scale) suggesting that the process of adipocere formation is still continuing, even though the temperatures have considerably decreased $\left(\sim 7^{\circ} \mathrm{C}\right)$ when compared to the initial temperature $\left(\sim 16^{\circ} \mathrm{C}\right)$.

Figure 5 shows the representative spectra for the samples collected after a three month postmortem submersion interval. The samples show very little variation when compared to the two months samples and as with all previous samples, there are no distinct differences between the samples collected at 10 and 30 feet. It is hypothesized that the process of further adipocere formation (to an advanced stage adipocere product) was inhibited during this month due to the rapid decrease in ambient temperature and the fact that the water temperature at the completion of the experiment $\left(\sim 1^{0} \mathrm{C}\right)$ was close to the freezing point. The samples are still considered to be in an intermediate stage of adipocere formation, as they were after the two month postmortem submersion interval.

The results of this study chemically confirm observational findings $[1,18]$ that suggest that adipocere can form in temperatures below those considered optimal for its formation. While adipocere formation was confirmed in cool water temperatures $\left(\sim 7-16^{\circ} \mathrm{C}\right)$ in this study, it appears that cold water temperatures will in fact prohibit further chemical conversion of the soft tissue to adipocere. This is most likely the result of the exclusion of decomposer organisms at colder 
temperatures, which is not conducive to their survival or proliferation. To date, there have been no chemical studies of adipocere formation in water temperatures which approached zero and therefore further studies are required to confirm this finding. This study also demonstrated that adipocere can form in as little as 30 days in a cool water environment, which is comparable to the observational findings reported by Kahana et al. [1] in seawater ( 38 days) and Anderson and Hobischak [24] in freshwater ( 9-35 days).

The variation in depth did not appear to impact the rate or extent of adipocere formation. All samples showed comparable lipid profiles at both 10 and 30 feet submersion. Anderson and Hobischak [24] also saw minimal variation in the degree of decomposition between carcasses submerged at $7.6 \mathrm{~m}$ and $15 \mathrm{~m}$ in seawater. However, they did observe greater differences between carcasses which floated versus those that remained in contact with the sea floor. As all of the samples in the current study floated during the bloat stage, it may explain why variations in decomposition, and thus adipocere formation, were not observed. Although a direct comparison with those studies which have identified adipocere formation at greater depths $[1,18]$ cannot be made, provisional findings suggest that adipocere formation can occur rapidly in freshwater and seawater, regardless of the depth or whether the body is submerged in the tropholytic or trophogenic zone.

Previous studies have reported several variables that may affect the likelihood of scavenging of soft tissue in aquatic environments. Containment within a vessel [1] or wreckage structure, as well as tight-fitting clothing [18], have been identified as factors which may inhibit scavenging activity. Additionally, whether the carcass sinks or float will dictate the type of scavengers that have access to the soft tissue [24]. The samples collected in this study showed minimal signs of scavenging, regardless of whether the tissue was fresh, decomposing or contained adipocere. Since the samples were neither contained in a vessel, nor covered in clothing, the lack of scavenging is most likely related to the wildlife population of Lake Ontario. The majority of large fish species are not scavengers and prefer to prey on live fish, while the smaller fish species can only consume small organisms such as snails, insects, clams and other crustaceans. In addition, some fish species (e.g. smallmouth and largemouth bass) feed very little during cold water periods, preferring to feed in the spring when temperatures become warmer and their metabolism increases. The postmortem placement of porcine tissue in Lake Ontario 
would therefore not be considered an attractive food source to most of the faunal population and the lack of scavenging may have assisted the ongoing formation of adipocere.

\section{Conclusions}

This study successfully demonstrated the rapid chemical conversion of adipose tissue to adipocere in a cool freshwater environment in the trophogenic zone of Lake Ontario. Diffuse reflectance spectroscopy was used as a diagnostic tool to demonstrate the chemical conversion process with minimal sample preparation and analysis time. The samples appeared to be in an early to intermediate stage of formation and it is hypothesized that the colder temperatures inhibited further formation to advanced stage adipocere, characterized by predominantly saturated fatty acids. The depth of submergence did not influence the chemical conversion process as similar stages of adipocere formation occurred at both depths investigated.

Scavenging and biomass loss was minimal over the duration of the study and may have aided the formation of adipocere in the porcine tissue. The study demonstrated that adipocere can form even on small amounts of soft tissue, which may be representative of dismembered or disarticulated limbs discovered in an aquatic environment.

\section{Acknowledgements}

The authors wish to acknowledge the assistance of the Toronto Police Service Marine Unit in setting up the experiment, conducting weekly observations and measurements, and collecting the samples. 


\section{References}

1. Kahana T, Almog J, Shmeltzer E, Spier Y, Hiss J (1999) Marine taphonomy: adipocere formation in a series of bodies recovered from a single shipwreck. J Forensic Sci 47:142-151

2. Yan F, McNally R, Kontanis EJ, Sadik OA (2001) Preliminary quantitative investigation of postmortem adipocere formation. J Forensic Sci 46:609-614

3. Fielder S, Graw M (2003) Decomposition of buried corpses, with special reference to the formation of adipocere. Naturwissenschaften 90:291-300

4. Forbes SL, Stuart BH, Dadour IR, Dent BB (2004) A preliminary investigation of the stages of adipocere formation. J Forensic Sci 49:566-574

5. Notter SJ, Stuart BH, Rowe R, Langlois N (2009) The initial changes of fat deposits during the decomposition of human and pig remains. J Forensic Sci 54:195-201

6. Dent BB, Forbes SL, Stuart BH (2004) Review of human decomposition process in soil. Environ Geol 45:576-585

7. O’Brien TG, Kuehner AC (2007) Waxing grave about adipocere: soft tissue change in an aquatic context. J Forensic Sc 52:294-301

8. Forbes SL, Stuart BH, Dent BB (2005) The effect of the burial environment on adipocere formation. Forensic Sci Int 154:24-34

9. Vane CH, Trick JK (2005) Evidence of adipocere in a burial pit from the foot and mouth epidemic of 1967 using gas chromatography - mass spectrometry. Forensic Sci Int 154:1923

10. Nushida H, Adachi J, Takeuchi A, Asano M, Ueno Y (2008) Adipocere formation via hydrogenation of linoleic acid in a victim kept under dry concealment. Forensic Sci Int 175:160-165

11. Fiedler S, Buegger F, Klaubert B, Zipp K, Dohrmann R, Witteyer M, Zarei M, Graw M (2009) Adipocere withstands 1,600 years of fluctuating groundwater levels in soil. J Archaeol Sci 36:1328-1333

12. Gill-King H (1997) Chemical and ultrastructural aspects of decomposition. In: Haglund WD, Sorg MH (eds) Forensic taphonomy: the postmortem fate of human remains CRC Press, Florida, pp 93-108 
13. Wilson AS, Janaway RC, Holland AD, Dodson HI, Baran E, Pollard AM, Tobin DJ (2007) Modelling the buried human body environment in upland climes using three contrasting field sites. Forensic Sci Int 169:6-18

14. Mant AK, Furbank R (1957) Adipocere - a review. J Forensic Med 4:18-35

15. Cotton GE, Aufderheide AC, Goldschmidt VG (1987) Preservation of human tissue immersed for five years in fresh water of known temperature. J Forensic Sci 32:1125-1130

16. Mellen PFM, Lowry MA, Micozzi MS (1993) Experimental observations on adipocere formation. J Forensic Sci 38:91-93

17. Sledzik PS, Micozzi MS (1997) Autopsied, embalmed, and preserved human remains: distinguishing features in forensic and historic contexts In: Haglund WD, Sorg MH (eds) Forensic taphonomy: the postmortem fate of human remains CRC Press, Florida, pp 483-496

18. Dumser TK, Turkay M (2008) Postmortem changes of human bodies on the Bathyal Sea floor - two cases of aircraft accidents above the open sea. J Forensic Sci 53:1049-1052

19. Stuart BH, Forbes S, Dent BB, Hodgson G (2000) Studies of adipocere using diffuse reflectance infrared spectroscopy. Vib Spectrosc 24:233-242

20. Stuart BH, Craft L, Forbes SL, Dent BB (2005) Studies of adipocere using attenuated total reflectance infrared spectroscopy. Forensic Sci, Med, Pathol 1:197-201

21. Notter SJ, Stuart BH, Dent BB, Keegan J (2008) Solid-phase extraction in combination with GC/MS for the quantification of free fatty acids in adipocere. Eur J Lipid Sci Tech 110:73-80

22. Parks Canada (2006) http://www.pc.gc.ca/progs/amnc-nmca/systemplan/itm4-/gla6_e.asp Accessed 23 January 2009

23. Environment Canada (2008) http://www.climate.weatheroffice.ec.gc.ca/climateData/canada_e.html Accessed 23 January 2009

24. Anderson GS, Hobischak NR (2004) Decomposition of carrion in the marine environment in British Columbia, Canada. Int J Legal Med 118:206-209 
Fig. 1 Comparison of water temperature at two depths in Lake Ontario

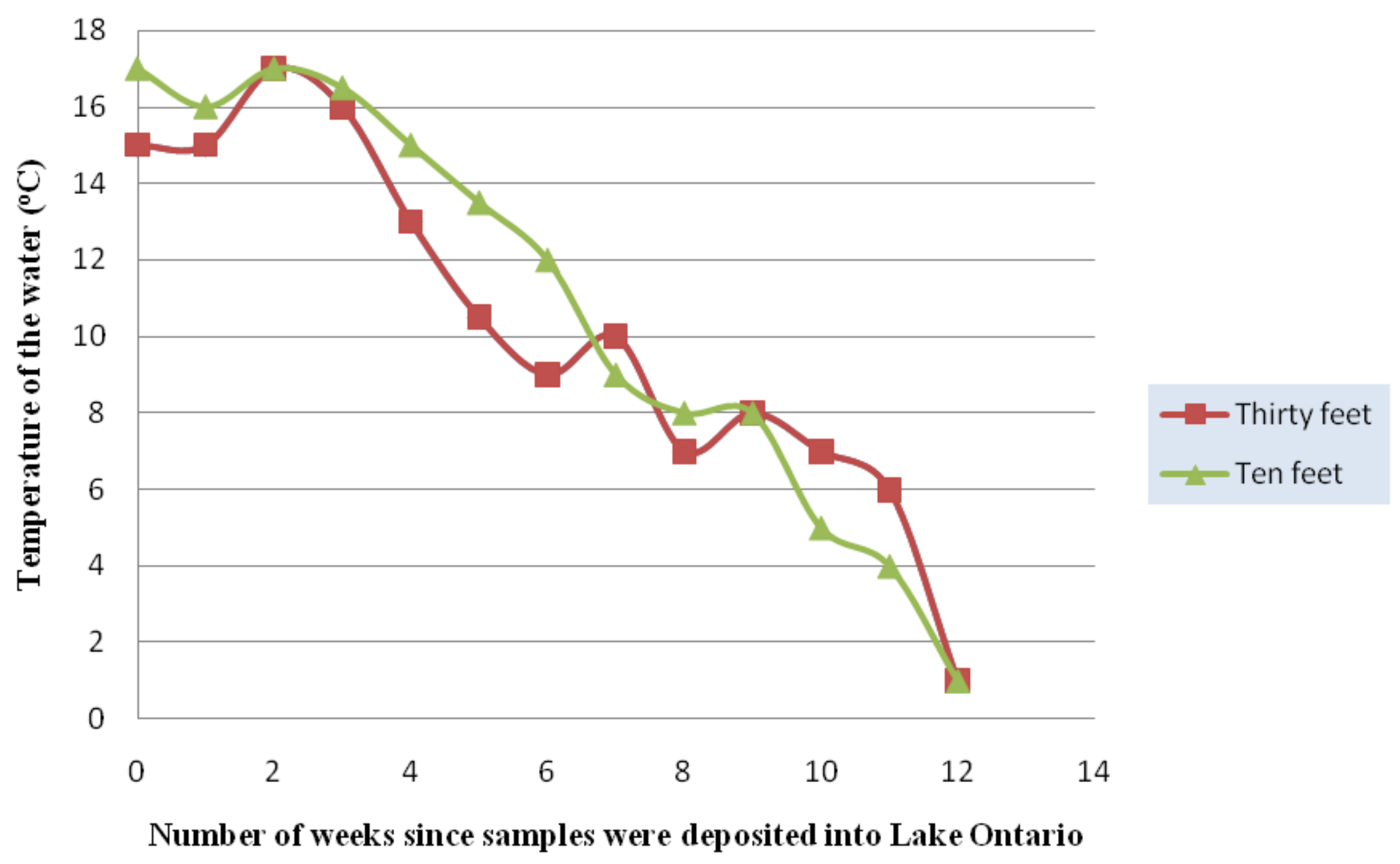


Fig. 2 Representative infrared spectrum of adipose tissue sample prior to submergence in Lake Ontario

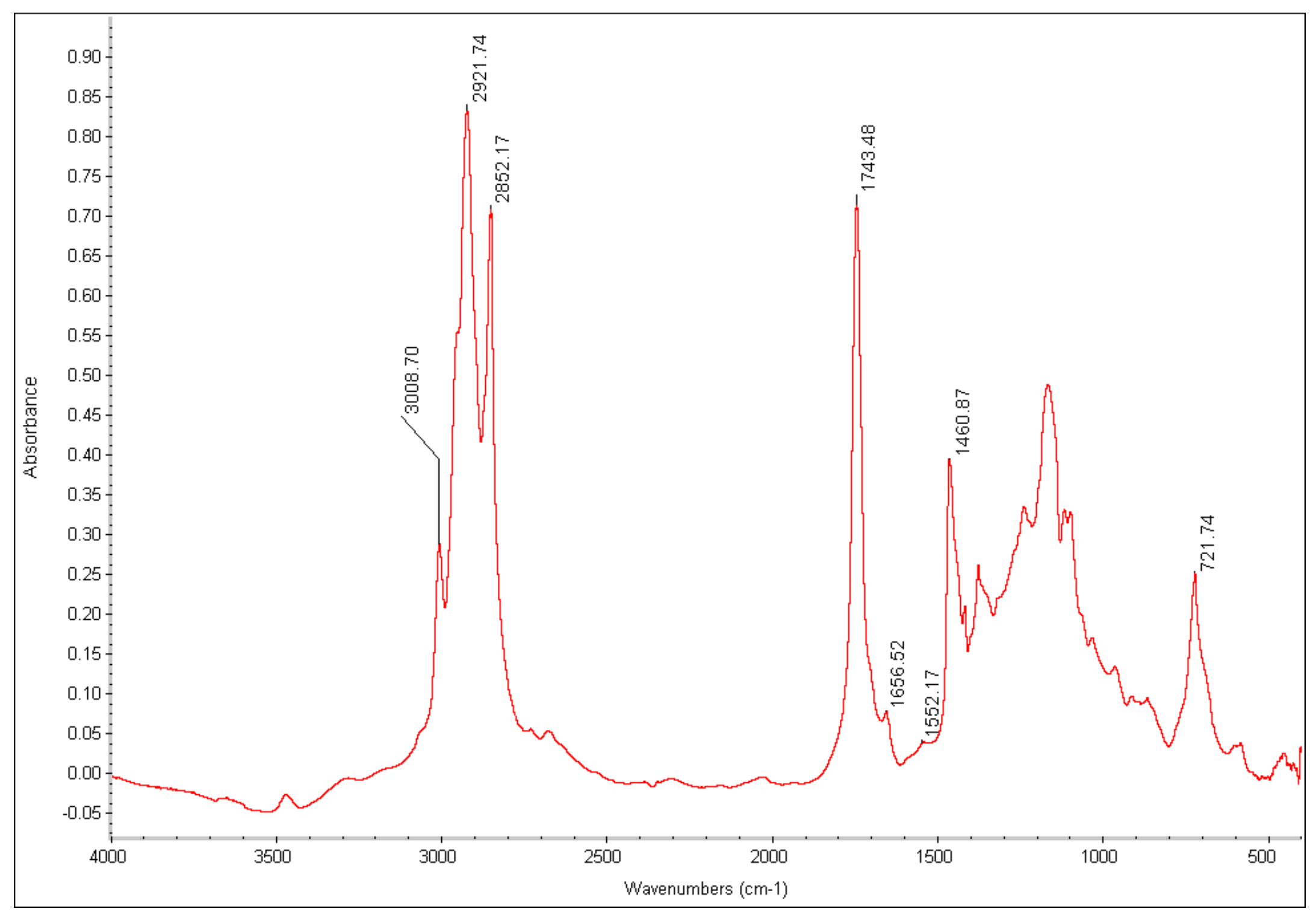


Fig. 3 Representative infrared spectra of samples collected at 10 feet (upper) and 30 feet (lower) after one month submergence in Lake Ontario

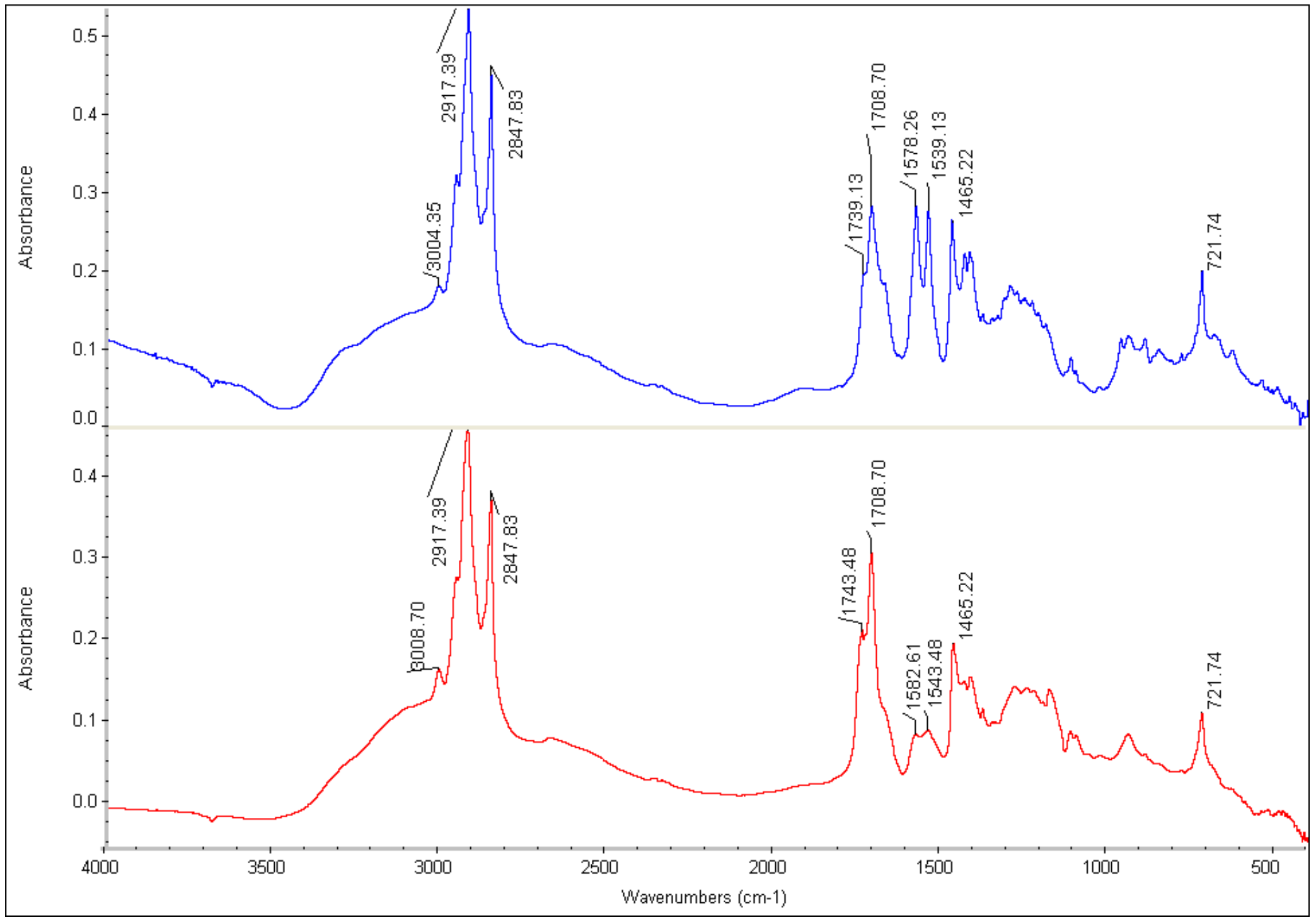


Fig. 4 Representative infrared spectra of samples collected at 10 feet (upper) and 30 feet (lower) after two months submergence in Lake Ontario

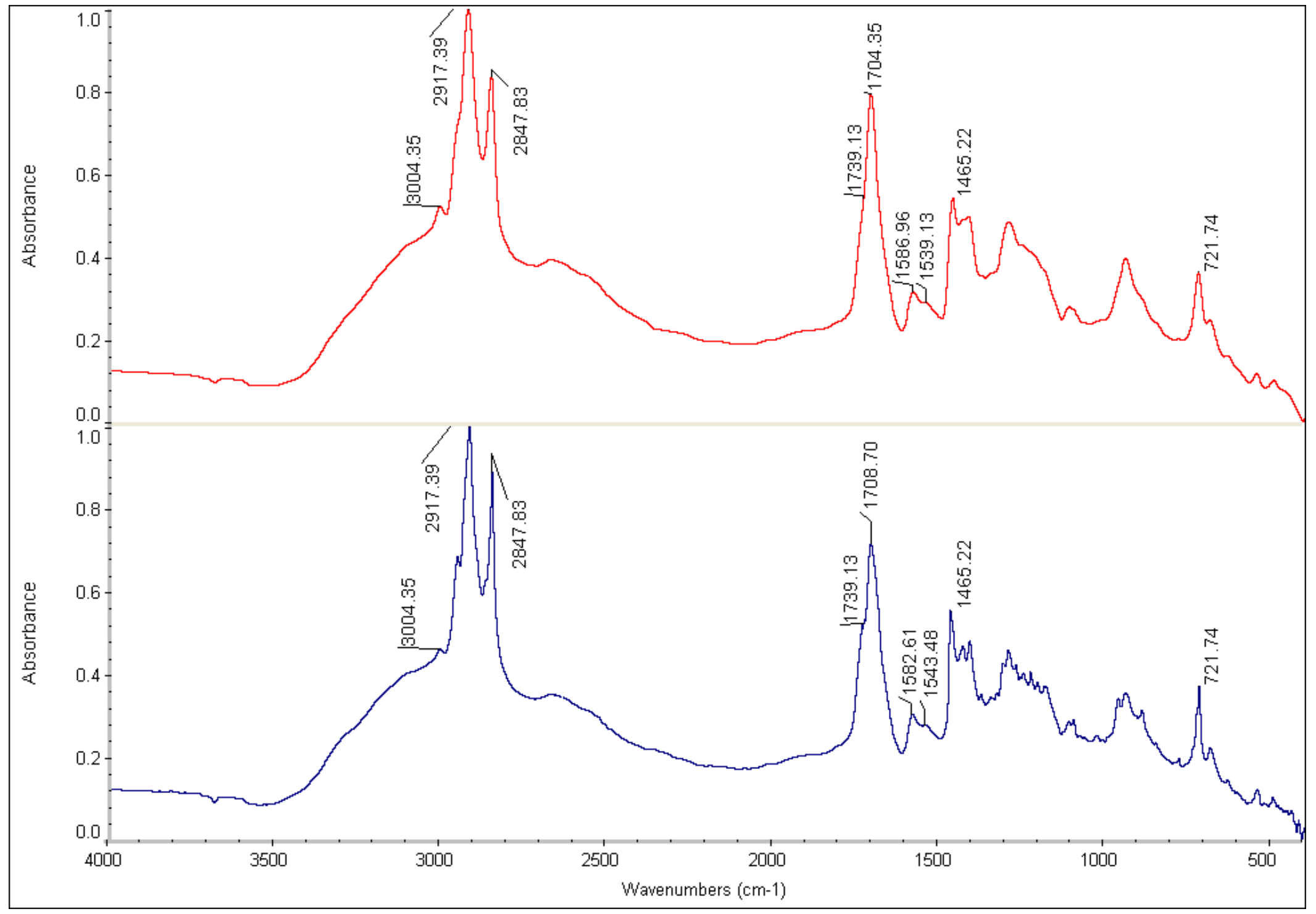


Fig. 5 Representative infrared spectra of samples collected at 10 feet (upper) and 30 feet (lower) after three months submergence in Lake Ontario

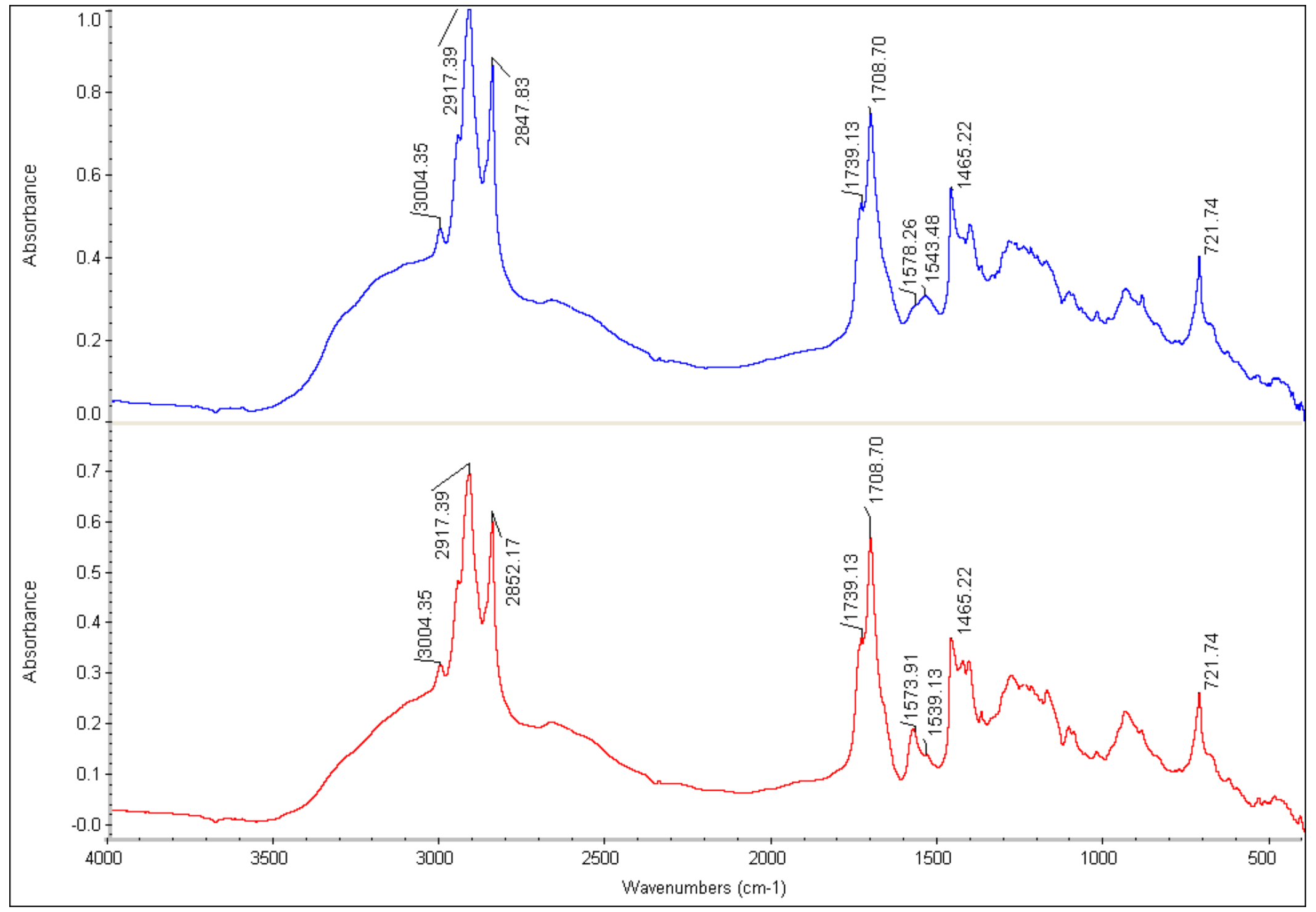

